\title{
FIRMIOR HERCULEA MUNDUS CERVICE PEPENDIT. SEARCHING FOR THE IDEAL FORM OF GOVERNMENT IN CLAUDIAN'S EPIC DE RAPTU PROSERPINAE
}

\author{
IVETA PASTYŘÍKOVÁ
}

\begin{abstract}
This article focuses on Jupiter's reign and on searching for the ideal form of government in Claudian's mythological epic De Raptu Proserpinae. It suggests an interpretation of Jupiter's reign which is based on the meaning of the two prefaces of the epic. The characters of the two prefaces, the first sailor in the first preface, and Hercules and Orpheus in the second one, are considered to be models of behaviour which are examined and problematized in the story of the epic. While the narrator does not evaluate Jupiter's reign explicitly, he presents it as a functional combination of Herculean and Orphean motifs and of the motif of the first sailor's audacity. Thus De Raptu Proserpinae offers its reader the opportunity to think about what the ideal form of government should be like.
\end{abstract}

Keywords: Claudius Claudianus; De Raptu Proserpinae; prefaces; order; progress; ideal form of government

In his quest for the golden apples of the Hesperides, Hercules held the heavens on his shoulders. As a result, taking the world upon one's shoulders becomes a symbol of succession to the throne, which means a demanding task and a heavy burden. ${ }^{1}$ Thus, in the panegyric epic De Consulatu Stilichonis by the late antique poet Claudius Claudianus, the military leader and regent of the Western Roman Empire Stilicho is compared i.a. to Hercules. According to Claudian, Theodosius, before dying, entrusted Stilicho with the whole world and Stilicho did not betray his trust.

ancipites rerum ruituro culmine lapsus

aequali cervice subis: sic Hercule quondam

sustentante polum melius librata pependit

machina... ${ }^{2}$

1 On this panegyric topos, see Gruzelier (1993: 159); cf. Claud. 3 (In Ruf. I), 273-274 and Paneg. Lat. IV $[\mathrm{X}], 16,6$. To understand the relationship of this motif to Aeneas' shouldering of the shield, see Hardie (1986: 369-375).

2 Claud. 21 (De cons. Stil. I), 142-145. 'With strength equal to his thou dost bear up the tottering structure of the empire that threatens each moment to collapse. Thus, when once Hercules upheld the 
Claudian's political poems set participants in public activities at that time in a mythological framework. By doing so, Claudian searches for new, more modern meaning in timeless myths. At the same time, these poems free specific events from ephemerality by linking them to archetypal myths. A smaller, but no less important part of Claudian's oeuvre stays fully in the mythical realm: his mythological epic. Even there, the poet reflects on real-world issues. One of them is the ideal form of government, one of the key themes of the mythological epic De Raptu Proserpinae, an unfinished poem consisting of three books. ${ }^{3}$ In this variant of the myth upon which the poem is based, Pluto threatens to destroy the whole world if Jupiter does not give him a wife. Jupiter allows him to rape Proserpina and Ceres, Proserpina's desperate mother, searches everywhere for her daughter and is willing to confront Jupiter himself. In the end, she teaches agriculture to humankind, as Jupiter wishes. This part of the story, however, remains only adumbrated in the opening synopsis (Claud. Rapt. Pros. I, 28-31). Thus, the story of the rape is a part of cosmological events: the fight between the forces of order and chaos. ${ }^{4}$ The heart of the story is Jupiter's concern for the world.

The theme of concern for the world order constitutes a connection between De Raptu Proserpinae and Claudian's political poems and we even find the image of Hercules holding the whole world upon his shoulders in this poem as well (although this time in connection with another person who takes care of the world):
te Libyci stupuere sinus, te maxima Tethys
horruit, inposito cum premere polo:
firmior Herculea mundus cervice pependit;
lustrarunt umeros Phoebus et astra tuos. ${ }^{5}$

Thus De Raptu Proserpinae, with the same key theme as Claudian's political poems, offers its readers an opportunity to think about the ideal form of government and compare Jupiter's rule with the political situation in the Roman Empire - both as it really is and as portrayed in Claudian's political poems. But as fruitful as a detailed comparison may be, for the purpose of the present article, we will confine ourselves to the theme of the ideal government in the mythological epic De Raptu Proserpinae, with some commentary on the relations between these two types of poems at the end of the article. However, the resemblance between the poems does show why the mythological epic

world, the universal frame hung more surely poised...' The Latin text of the quoted political poems is taken from Hall (1985). Translations of Claudian's political poems by Platnauer (1963).

3 The thematic similarity between both types of poems has already been mentioned by Dutsch (1991), Duc (1994: 149-272) and Kellner (1997: 284-287). The most explicit depiction of the ideal ruler is a long speculum principis (Claud. 8 [Paneg. Hon. cos. IV], 214-418), namely Theodosius' speech to his son Honorius about what a good ruler should be like.

4 On the dualism of order and chaos and good and evil ("Heaven and Hell") in the Roman epic, see Hardie (1993: 57-87) who emphasizes the instability of an equilibrium persistently disturbed by the forces of chaos ("Hell"); on the opposition of order and chaos in the epic De Raptu Proserpinae, see Wheeler (1995) or, for example, Ware (2012: 130, 184-186).

5 Claud. Rapt. Pros. praef. II, 45-48. 'At you the gulfs of Libya were astonished, at you mightiest Ocean shivered when you were weighed down by the burden of the heavens: the sky was poised more firmly on Hercules' neck; Phoebus and the stars moved in procession round your shoulders'. The Latin text and translation of De Raptu Proserpinae by Gruzelier (1993); it will be referred to below only by the number of the book / preface and the number of the verse. 
De Raptu Proserpinae can also be read as a reflection of a political reality (and not only as a self-contained fictional story) and that the question of the ideal government in $\mathrm{De}$ Raptu Proserpinae is really important. ${ }^{6}$ We will thus attempt to determine what kind of ruler Jupiter in De Raptu Proserpinae is. He gave his own daughter to the god of the dead, allowed him to enter his realm, and encouraged the goddess Ceres to revolt. Did this mythic ruler keep the world stable despite these events; did he manage the difficult task of taking care of the world? Could he be considered a model for a real-world ruler?

As mentioned above, an important connection between the political poems and De Raptu Proserpinae is the motif of Hercules holding up the whole world. Both in the political poem De Consulatu Stilichonis and in De Raptu Proserpinae, Hercules is compared to a politician known from the real world. In De Raptu Proserpinae, such an explicit comparison is, however, limited to the preface of the poem. Not without reason: the preface is a "threshold" which belongs to the poem, but is not a part of the narrative of the poem. It reaches out of the poem to address the reader, as it were, because the poet reflects on his work in it, so it provides direct connections between the mythological story and the actual world. ${ }^{7}$ The poet adds two prefaces to De Raptu Proserpinae (to the first book of the epic and to the second one), both composed in elegiac couplets and thus different from the hexametrical epic itself. They present a reflection on the creation of the epic but there is also a connection with the theme of the epic. They help readers form an idea of the ideal form of government: ${ }^{8}$ the prefatorial characters assume different attitudes toward order and chaos and can even be seen as embodiments of these attitudes. Therefore we will focus first on the prefaces and then on the narrative in the epic.

\section{The first preface: the first sailor and progress}

The shorter preface to the first book (12 verses) of the epic depicts the success of the first sailor who builds a ship, moves away from the shore with growing audacity, and then defeats the stormy sea. The preface is usually considered to be an allegorical reflection

6 The connection between the government on earth and the stability of the universe, the cosmos, is a characteristic feature of the epic genre. Mythological stories can reflect current issues - "after Virgil could any mythological epic escape such a reading?" asks Hardie (1993: 65) rhetorically. On this topic, see Ware (2012: in particular 128-129 where she deals with this question in a nutshell) and especially Hardie (1986) who examines the relationship between cosmos and imperium in the Aeneid in particular (on cosmological themes in the so-called Silver Age of Latin literature, see Hardie 1986: 381-383). On the relationship between mythological or cosmological themes in De Raptu Proserpinae and political reality, see also Wheeler (1995: 132-133).

7 On prefaces in general and in late antique poetry, see Pelttari (2014: 45-72). Moreover, there are other very direct connections: the mythical world of the poem sometimes resembles reality: for example, Jupiter is depicted as an authoritative absolute ruler - the council of the gods consists only of Jupiter's speech, by which he tells other gods his decision and which also contains a threat to those who dare disobey (Gruzelier 1988: 63). However, there can also be another reason for such a depiction of the council: Claudian's preference for monologues in his scenes. Furthermore, the narrator cannot help adding a brief commentary in key scenes by which he explicitly connects the myth with reality: the story unfolds in the times when the Tiber was not adorned with tropaea (II, 176-178).

8 Schmitz (2004) was the first scholar who pointed out the thematic similarity between the prefaces and the rest of the epic. 
of the poet's artistic career: the poet sets out over open sea (i.e. a big epic poem) after making some minor attempts. ${ }^{9}$

Another interpretation can be made beside the meta-poetic one. Because the key theme of this preface is progress, this emerges as the connection with the main story: Jupiter encourages human progress through the rape of Proserpina. The goddess Ceres teaches one man how to cultivate corn out of gratitude for informing her about her daughter. Having learned how to grow corn, humankind enters the stage of culture, leaving behind the pre-civilisation stage.

Entering the sea was often perceived negatively because it terminated the so-called Golden Age. The boundaries between earth and sea disappear and humans enter a realm where they do not belong. ${ }^{10}$ In this preface, the first sailor ventures on daring journeys quas natura negat (praef. I, 4), which nature forbids: he runs the risk of entrusting his ship to unreliable winds (dubiis ... flatibus, praef. I, 3). Although his deed violates the natural order (natura), he is not condemned at all. On the contrary, the preface ends with the first sailor's victory. And he becomes a cultural hero who defeats the stormy sea (domat, praef. I, 12). ${ }^{11}$ The sailor's increasing praeceps audacia (praef. I, 9) has rather positive connotations. It is not impetuous impudence ${ }^{12}$ but rather courage that drives the sailor forward. He moves slowly and step by step (paulatim, praef. I, 9) and is guided by the sky, or by the world order, which the gods guarantee (caelumque secutus, praef. I, 11).

Given the very schematic character of the sailor (we do not know anything about his identity except his sailing experience), this first sailor can be viewed as a model example of violating order but for the greater good, for progress, and thus for a better world order.

\section{The second preface: Hercules, Orpheus, and varying ways to peace}

The considerably longer second preface (52 verses) is even more important for the concept of the ideal form of government. It is based on the comparison and contrast between two mythical characters: the singer Orpheus and the hero Hercules. At the beginning of the preface, Orpheus lays aside his lyre. The moment he becomes silent, the beasts return to wildness and the surroundings are not safe. Then (praef. II, 9-12), Hercules comes to the Thracian realms to tame dangerous monsters, Diomedes' horses. Orpheus seizes his lyre again; as soon as he starts singing, everyone is fascinated and listens to him and harmony is restored. Not only does Hercules inspire Orpheus to sing,

9 See e.g. Gruzelier (1993: 79-82). On the possibility that it is about the first ship Argo, see e.g. Felgentreu (1999: 161) or Ware (2004: 184-185). As one reviewer of the first draft of the article points out, the allegory of entering the open sea may also refer to Claudian's originality and his attitude to the literary tradition. To consider this possibility, see Pelttari (2014: 6-7).

10 Cf. e.g. Ov. Met. I, 94-96 (termination of the Golden Age), Hor. Carm. I, 3 (impiety of entering the sea) and see Gruzelier (1993: 81-82).

11 This is why Schmitz (2004: 39-45) puts emphasis on the binary opposition ars vs. wild nature. According to her, this constitutes the key theme both of this preface and of the second one, although she also mentions the motif of progress.

12 Cf., on the contrary, the monster Audacity / Rashness in Claud. 3 (In Ruf. I), 34: caeco praeceps Audacia vultu 'foolhardy Rashness with sightless eyes'. 
he also becomes a part of his song: Orpheus praises him with his singing. In his song, he narrates Hercules' whole life, up to the taking the world upon his shoulders.

The preface can be interpreted meta-poetically: the poet identifies Hercules explicitly with a certain Florentinus (praef. II, 49-50), the urban prefect of Rome in 395-397 AD, ${ }^{13}$ and consequently, Orpheus with himself. Thanks to Florentinus, the poet continues to write his epic after a long pause. ${ }^{14}$ However, the preface is connected with the main story by a key concept too, this time the idea of peace and defeating dangerous forces (pacifero ... pede, praef. II, 10). ${ }^{15}$ Orpheus and Hercules struggle with subversive elements in the preface and similarly, the world order of the main story of the epic is permanently being threatened. Jupiter deals with strong opponents: first, the ruler of the underworld threatens to shatter the world order to pieces with a destructive war, then the goddess Ceres makes a stand against Jupiter himself, the bearer of the world order in order to get her daughter back.

Orpheus and Hercules bring peace to the world, their lives intersecting in Thrace, in the wild setting; however, each of them represents a different model approach to the dangerous forces that threaten peace, the balanced world order. ${ }^{16}$ Orpheus is a harmony-maker: his singing tames dangerous winds and waves (frenantur, praef. II, 17). While he is singing, there is harmony between does and tigers (concordes, praef. II, 27) and fears are replaced by playful games (cf. securum ... leporem, praef. II, 25; ludunt, praef. II, 27). On the contrary, Hercules is adorned with bloody victories (cf. rubuit Busiride Nilus, praef. II, 43), and his peace is made with violence (cf. Thracia pacifero contigit arva pede, praef. II, 10). ${ }^{17}$ Thus they embody two different ways of coping with disorder or chaos. The Herculean approach to chaos is to destroy the dangerous forces which threaten order; the Orphean one to erase the dangerousness of these forces and to make them coexist in harmony.

The parallel narrative lines focused on such different (and schematic) characters are interwoven by the end of the preface: Hercules brings peace; consequently, Orpheus starts singing; as he relieves all the discords by his singing, he is the harmony-maker himself. The mythical singer composes a kind of a panegyric to Hercules ${ }^{18}$ and he addresses him directly in his songs, praising him. The opposite pathways to peace are interconnected

13 See Leppin (1998: 564). On an old theory, which was based on the assumption that it is Stilicho himself who is referred to, see Cameron (1970: 453-454).

14 There may be another reason why Florentinus is being praised here: he took charge of corn distribution during his prefectship and took this task over from Stilicho (see Gruzelier 1993: 18-19 and 159). On this preface, see also e.g. Dutsch (1991:217-218), Felgentreu (1999: 169-179) or Ware (2004: 185).

15 '[P] eace-bringing foot'. Cf. in the main story pacificas rubri ... fulminis alas 'the peace-imposing wings of his bright-red thunderbolt' (II, 229). This motif is emphasised also by Schmitz (2004: 52-54).

16 Wild beasts and monsters are, of course, not the same, but both types of beings represent dangerous forces threatening peace. Moreover, Orpheus spreads harmony among monsters as well (in other texts, see e.g. Furies in the underworld in Ov. Met. X, 45-46, who are suddenly silent and stunned; in this poem, see the Orphean enchanting song, towards which they stretch their crests [I, 12-14]). Besides peacemaking, Orpheus and Hercules have another thing in common: a descent to the underworld. Each of them displays his character here. Hercules abducts Cerberus by force, Orpheus enchants him by his singing - see e.g. Ov. Met. X, 64-67 and Verg. Georg. IV, 483 and cf. Schmitz (2004: 54, n. 39), who, in contrast, highlights the similarity between the heroes' deeds. Nevertheless, this connection between Hercules and Orpheus is not mentioned in the preface. See Hardie (1986: 110-118) who covers the theme of Hercules fighting chaotic forces in the Aeneid.

17 '[T]he Nile grew red with Busiris' blood'; '[R] eached the fields of Thrace with his peace-bringing foot.'

18 See Schmitz (2004: 55). 
with this bond between the representatives of these two opposing methods. ${ }^{19}$ Therefore, there is also the hint that these opposite approaches could be interwoven.

We can find the concept of progress here as well: Hercules is always being urged to action by his stepmother Juno. The poet refers to stimuli, goads (praef. II, 29), which are defined as "attacks" but also as "stimuli" (goads in a figurative sense) for Hercules' amazing successes. Having throttled snakes sent by Juno with his own hands when he was just a baby, Hercules did not stop performing heroic deeds and freeing the world from monsters. In Orpheus' narrative, Hercules reaches the peak of his life by taking the world upon his shoulders (praef. II, 45-48). The career of the monster slayer, wandering the world, thus culminates in his assuming responsibility for it. Such a successful life can be viewed as a model for progress: a negative experience such as deprivation or misery is needed to achieve an objective.

\section{Jupiter's reign: order and progress}

The main narrative of the epic is far more complicated than the mini-narratives in the two prefaces and no characters from them appear there. However, as we have seen, the first sailor, Orpheus, and Hercules personify model approaches to the world order, and these approaches are examined and problematized in the main story of the epic.

We can see several characters in this story whose behaviour is beyond the normal order. Even after the Olympian world order was established and the war with the Giants finished, chaos is not completely eliminated. The situation is a bit more complicated than in the very schematic prefaces: a certain limited amount of "otherness" does no harm (or not much at least) to the world order and some characters walk the line between order and chaos. ${ }^{20}$ As long as the stability of the world order is not threatened, Jupiter does not have to intervene. The absolute ruler of the gods starts to worry when the "otherness" gets out of control and thus becomes dangerous to the world order. It is Pluto who poses the biggest threat to Jupiter, and another threat is the goddess Ceres. The ruler of the underworld erupts into anger because unlike Jupiter, he does not have any offspring and he threatens to declare war on his brother. Fratricidal war is prevented only by the prostrations of the old Parcae, who bow down before the infuriated ruler, touching his knees and begging:

ne pete firmatas pacis dissolvere leges,

quas dedimus nevitque colus, neu foedera fratrum

civili converte tuba. ${ }^{21}$

19 The mutual relationship between both characters culminates at the end of the preface where Florentinus-Hercules is praised as the leader of the Muses. (On this Hercules Mousagetes, see Hardie 2007: 563-564.)

20 This is the case with Ceres' wild mother Cybele and with Pluto, who are close to chaos but at the same time parts of the world order. Pluto, as the ruler of the underworld (chaos, II, 196), is so frightening that not even a monster as terrible as Cerberus dares interrupt his speech with barking (II, 85-86), but he is, however, one of the rulers of the world. On the confusion of good and evil in the Aeneid and in the post-Vergilian epic, see Hardie (1993: 73-87).

21 I, 63-65. 'Do not seek to dissolve the established laws of peace which we have given and our distaff has spun, nor overturn the bonds of brothers with the trumpet blast of the civil war.' 
Pluto has demonstrated his dangerous character, due to which he is close to the forces of chaos: he is ready to destroy the world order and peace instead of trying to negotiate. In the end, he is willing to do this because of the intervention of the Parcae. Mercury, the only god who makes communication between the two worlds possible, delivers Pluto's request to the ruler of the gods. Nevertheless, Pluto does not forget to add a threat of what will happen if Jupiter refuses him: he is going to break all boundaries, destroy the world order, and throw the world into chaos.

patefacta ciebo
Tartara, Saturni veteres laxabo catenas,
obducam tenebris solem, conpage soluta
lucidus umbroso miscebitur axis Averno. ${ }^{22}$

And Jupiter complies with his request. Pluto, following his brother's instructions (germani monitu, I, 279), leaves the underworld in order to rape Proserpina so that he can later marry her. Paradoxically, Jupiter lets him follow through on many of his threats. Pluto breaks boundaries (victa manu duros Trinacria nexus / solvit, II, 186-187), ${ }^{23}$ violates the established world order (astra viarum / mutavere fidem, II, 188-189), ${ }^{24}$ and brings darkness and death to the world (III, 235; III, 240) as well as a new evil (the Sirens, III, 256-257). Jupiter seems not to have fulfilled his responsibility as a good ruler to protect the world. The other deities criticise him, although mainly for being a bad father, for letting the frightening ruler of the dead capture his own daughter. Jupiter, however, sacrifices Proserpina for the greater good, namely to prevent a devastating war, even with someone who participates in ruling the world. He permits Pluto to enter the upper world and to violate the world order because it is a temporary and controllable violation, in the contrast to an imminent war. ${ }^{25}$

Thus, Jupiter has to compromise sometimes - to not try to preserve his world order by force, but to let chaos in so that a furious attack of chaos cannot destroy the stability of the

22 I, 113-116. 'I will lay open and stir up Tartarus, I will unfasten the ancient chains of Saturn, I will obscure the sun with darkness, the structure of the world will be loosened and the shining heavens will be mingled with shadowy Avernus.'

23 'Sicily, subdued by his hand, loosened its hard bonds.'

24 '[T] he stars abandoned allegiance to their courses'; cf. paene reluctatis iterum pugnantia rebus / rupissent elementa fidem... ('The elements, once again fighting with resisting matter, would have almost broken their bond', I, 42-43).

25 Pluto follows Jupiter's instruction and, what is more, darkness disappears as soon as Pluto leaves (III, 243). On this sacrifice which preserves peace between heaven and hell, see e.g. Wheeler (1995: $116 ; 123-131)$; on the importance of sacrifice in the epic generally, see Hardie (1993: 19-56). Wheeler employs René Girard's concept of a victim used as a scapegoat in order to restore social order (developed by Girard in Violence and the Sacred in 1977). Thus, Proserpina serves as the surrogate victim who helps prevent the war between Jupiter and Pluto (Wheeler makes use of an addition to Girard's theory, introduced by Patricia Joplin in 1984, who sees the exchange of women between political rivals as an exchange of violence: these women function as surrogate victims for the group). This approach urges Wheeler to view Ceres' subsequent revolt as making the efficacy of the sacrifice problematic, because instead of the restoration of the world order, another threat of chaos arises (Wheeler 1995: 116 and 128-131). Consequently, Wheeler sees the chaotic nature of Ceres' revolt as unambiguously negative (although he concedes that "a return to chaos means not only the end of the world but also a return to its beginning", to origo mundi (Wheeler 1995: 121). In contrast to this approach, my approach is based on the importance of chaos in the process of creating a new world order - see further n. 52 . 
world and shatter it to pieces; ${ }^{26}$ especially when that order is threatened by someone who participates in it to some degree. The Herculean model approach to chaos (i.e. the violent destruction of chaos) proves to be insufficient. It seems suitable for the times when the Olympian order was being established: then an uncompromising fight was appropriate for example the fight with the Giants whose bones, heaped in a pile, whiten in an ancient grove on the slopes of Etna (III, 341-342). ${ }^{27}$ Present-day Jupiter resembles Hercules doing his greatest deed, taking the whole world upon his shoulders. The journey from Hercules, the monster slayer, to Hercules, responsible for the whole world is, therefore, mirrored in Jupiter's wars with the Giants and his subsequent responsibility for the world. ${ }^{28}$ On the contrary, the goddess Minerva represents the Herculean approach to dangerous forces completely. ${ }^{29}$ She blows up at Pluto, using angry words to call him the force of chaos ${ }^{30}$ and does not hesitate to appeal to arms. She helped Jupiter conquer Typhon once and this monster is depicted on her helmet. ${ }^{31}$ This kind of situation does not occur again: the goddess is not allowed to conquer Pluto. Jupiter throws his thunderbolt - but not in order to punish the intruder, but to express his consent to Pluto's actions and to stop Minerva. It is a peace-bringing thunderbolt (pacificas rubri ... fulminis alas, II, 229), ${ }^{32}$ yet this peace is different from the peace that Hercules brings to Thrace (pacifero ... pede, praef. II, 10). Jupiter's attitude of compromise is similar to Orpheus' bloodless peace; it is, however, distant from Orphean harmony. The war is prevented but Proserpina is crying, Diana is sad, and Ceres, Proserpina's mother, falls into despair. Orpheus erases every conflict and makes the sheep and the wolf the best of friends; Jupiter solves the crisis but he does not eradicate the conflict.

Is Jupiter's reign too cruel? It is definitely forbidding - but could it be milder, more Orphean?33 The model of Orphean harmony also has shortcomings and, as a result, cannot become the model for an ideal form of government. Orpheus tames nature with his art, but he is interconnected with nature as well (nature rejoices while he is singing and mourns while he is silent, praef. II, 17-28; 1-8). He is, therefore, not far from a natural, pre-civilized existence, which is not in agreement with Jupiter's ideal, as will be demonstrated below. ${ }^{34}$ Moreover, Natura is not only teeming with abundant fauna and flora but also functions as a limiting and classifying principle: everything has its own natura,

26 Cf. Vítek, Starý (2010: 40).

27 Jupiter does not want to take such a strong action against the underworld as Hercules did, according to the myth (see n. 16). In the preface, Hercules deals with Diomedes' man-eating horses but Jupiter does not oppose Pluto's terrifying horses who are yoked by a Fury herself and whose neighing scares even Atlas (II, 191-192).

28 On Hercules taking part in conquering the Giants, see e.g. Kerényi (2013: 32). Sometimes, similarity between Hercules and Jupiter is highlighted: Jupiter has defeated the Titans and the Giants and does not stop caring for his kingdom even after finishing fights, Hercules has freed the world from monsters and then, as a one of gods, takes care of the world and supports brave men (Paneg. Lat. XI [III], 3, 4-6).

29 Well-known Hercules' helper (see e.g. Eliade 1978: 280).

30 She advises him to marry monsters and says that only they are suitable for him (II, 218-219).

31 See Gruzelier (1993: 165-166).

32 '[T]he peace-imposing wings of his bright-red thunderbolt.'

33 Orpheus is, of course, not a governor but he (like Hercules) deals with dangerous forces and masters them, so he could be compared to Jupiter who has to deal with dangerous forces as well.

34 On Orpheus' connection with nature, see e.g. Johnston (1980: 106-124) or Perkell (1989: 69-70). Orpheus' activity cannot be, therefore, regarded as ars defeating wild nature (pace Schmitz 2004: 39-45). 
its own nature (cf. also praef. I, 4). Here comes the difficulty with the Orphean model: Orpheus' bewitching singing breaks through boundaries and breaking boundaries is equivalent to amorphous chaos, as Pluto's raid has also shown. ${ }^{35}$ The depiction of Mount Etna in the epic reveals how dangerous Orphean harmony is. Etna belongs to mirabilia beyond the normal order. On the mountain, frost and heat unite in admirable harmony. ${ }^{36}$ Nevertheless, Mount Etna spews ominous clouds, spurts terrifying lava flows into the sky (I, 163-165) and turns water into its opposing force, into fire. Wind searches for its way to freedom just like rebellious Enceladus (I, 155-159 and 173-178). ${ }^{37}$

The miraculous metamorphosis of the underworld during Pluto's wedding with the abducted Proserpina also serves as a warning of the dangers hidden in an idyll. It is not Jupiter's intention to take strong action against the enemy from the underworld and to follow the Herculean pattern, but he does not make it his goal to make an idyllic place of the underworld either. ${ }^{38}$ If this were his intention, he would be acting very unwisely and would be violating the world order himself. Pluto's wedding does bring harmony to the underworld because the girl behaves as an orphic character to some extent: ${ }^{39}$ she gives

35 On limitlessness, and the blending and blurring of boundaries as typical features of chaos, see Vitek, Starý (2010: 16; 27); cf. Claudian's Gigantomachia. The minute Orpheus stopped singing, the beasts found their saeva ... natura (praef. II, 5) renewed. Thus, it was their own true natura that they lost when Orpheus began to sing. What, then, has been left to the beasts when deprived of their nature? If they are turned into something else and are not themselves anymore, the boundary between beasts and domestic animals is broken.

36 Heat and frost do not impede each other: scit nivibus servare fidem pariterque favillis 'it knows how to keep faith with the snows and equally with the hot ashes' (I, 167). It itself is not surprising (all the elements of the world are interconnected with fides - cf. e.g. I, 42-43). What is surprising is that the opposites are united in one place and their relationship is so idyllic that fumoque fideli / lambit contiguas innoxia flamma pruinas 'and the flame harmlessly licks the nearby frost with smoke that is loyal to its pledge' (I, 169-170).

37 By the way, Mount Etna is connected essentially with the revolt of the Giants: the above-mentioned ancient grove is a monument to the past, of Jupiter's victory over them. Chaos can, however, wake up again: adhuc crudele minantur / adfixae truncis facies 'faces nailed to tree-trunks still threaten cruelly' (III, 340-341). According to Guipponi-Gineste (2010: 50), there is concordia discors on the peak of Mount Etna, as anywhere in the world of this poem. Cf. also Kellner (1997: 264). Both of them put emphasis on the similarity of relationships among characters of the epic, like Schmitz (2004: 50-54). It makes a substantial difference, however, whether harmony is created by force or in an idyllic way. In this case of Etna, even now at least partly exempt from cultural world (teritur nullo cultore cacumen 'the summit is not trodden by any farmer [or generally cultivator; my note]', I, 162), it is an idyllic harmony. But a threat is hidden in this harmony, as has been shown above. The Orphean elements also have their horrible counterparts in the epic. They are mostly Bacchean elements, not only interconnected with nature as Orphean elements but also with the total absence of culture, with the collapse of the world order (cf. for maenads so typical features as sparagmos and omofagia - see e.g. Eliade 1978: 365). The character of Cybele is also made of Bacchean elements (e.g. bacchatur, II, 208), although she is a tamer of wild animals, like Orpheus (Ov. Fast. IV, 217-218). Something Bacchean is also in Ceres (bacchatur, II, 269) and in Proserpina (in II, 62-70, she is compared to a nymph celebrating Bacchus' feast), who is an Orphean person at the same time (see next paragraph and n. 39). The thin boundary between harmony and wildness is demonstrated also by a sudden transformation of the formerly harmless Sirens' song into harmful one (III, 254-258). Schmitz (2004: 43), in contrast, does not infer any threats connected with enchanting singing from the similarity between Orpheus and the Sirens.

38 Cf., in contrast, Schmitz (2004: 46-54) or Wheeler (1995: 127-128). Jupiter's declared intention in the speech to Venus is rather love passion than quiet harmony: cur ultima regna quiescunt? / nulla sit inmunis regio nullumque sub umbris / pectus inaccensum Veneri ('why should the lowest kingdom be at peace? Let no region be exempt and no breast among the shades be unfired by Venus', I, 224-226, my emphasis). Moreover, Jupiter is trying here to incite Venus to quick action: the emphasis put on love could be thus utilitarian.

39 See Schmitz (2004: 46-52). 
joy to the whole house where she lives by singing; Pluto becomes calm after seeing her; and most importantly, when she enters the underworld, the punishment of those who are condemned forever stops (II, 333-342). The dark kingdom transforms into an idyllic place where merry Furies let their snakes drink wine and where cheerful songs are heard. Nevertheless, no one dies in the world (II, 354-360). Charon, decorated with reed, sailing the underworld river, singing and having no work to do (II, 359-360) may complete the carefree hilarity of the moment; but as a permanent condition, the nonexistence of death would be unsustainable. In the world where death is absent, the whole order of which death is a part is absent. And what function would the underworld have if nobody came to it? 40

This is why Orphean harmony is not the ideal and universal pattern of peace making. ${ }^{41}$ The seeming idyll of lack of conflict and boundaries is not an ideal condition, and harmony has to prove as illusory after some time: it can easily turn into evil chaos. ${ }^{42}$ Moreover, Orphean motifs are interconnected with the motives of the so-called Golden Age in the poem. A trickle of the Golden Age completes the underworld harmony: underworld rivers suddenly fill themselves with milk and wine (II, 351-353). ${ }^{43}$ Like the Orphean idyll, the Golden Age, void of all boundaries, ${ }^{44}$ cannot be the ideal condition either. This carefree period for humanity is also connected with evil, like the suspicious Orphean harmony: this time with Saturn's reign. Saturn is Jupiter's father but at the same time a cruel tyrant who the enraged Pluto threatens to set free from prison. Saturn's reign was, therefore, an ambivalent tangle of idyllic and savage elements; it was not a world order in the strict sense of the term because it consisted of unrestrained enjoyment and reckless cruelty. The Orphean elements with the Saturnian ones make a net, which is based on a loose world order (or maybe even not-order) and the pre-civilised way of living. ${ }^{45}$ Leaving aside Saturn's character, it is the barbarism of the Golden Age itself that makes Jupiter to terminate it after assuming his reign. ${ }^{46}$ Saturnia ... otia (III, 20-21), the "Saturnian ease", gave people the opportunity to enjoy a life of plenty without lifting a hand. There was no progress because there was no need to invent anything new; there was an abundance of everything. Jupiter stimulated people to exert themselves (sollicitae placuit stimulis inpellere vitae, III, 23), ${ }^{47}$ to set off culture, as he mentions in the council of the gods.

40 See Parcae's speech to Pluto: Nam quidquid ubique / gignit materies, hoc te donante creatur / debeturque tibi... ('[F]or whatever matter brings forth anywhere is created at your gift and is owed to you, and after the fixed detours of time souls are despatched once more into the confines of flesh...', I, 59-60).

41 Cf., in contrast, Schmitz (2004: 54). According to her, Orpheus functions as "Prototyp des Friedensund Kulturbringers".

42 See Chlup (2007: 186-192).

43 These are gifts of fertile Mother Earth, in an idyllic way unlimited in her generosity. (Cf., however, the dangerous similarity between this idyll and the behaviour of Maenads: they gain water, milk, wine and honey from the earth; to consider this similarity, see Segal 2001: 118.) According to Pluto, aurea progenies 'a golden generation' (II, 286) is ever-present in the underworld, yet during the wedding, the Golden Age spreads over the whole underworld.

44 See. e.g. Ov. Met. I, 89-112. Harmony among the animals listening to Orpheus' singing resembles the Golden Age - see Gruzelier (1993: 155-156) or Perkell (1989: 69-70).

45 On interdependence of almost divine life of humankind and natural or almost animal elements in Greek concepts of the Golden Age, see Chlup (2007: 194-195).

46 On the Golden Age in Claudian's oeuvre, see Ware (2012: 171-230).

47 'I decided to urge [them] on with the spurs of an anxious life.' 
Nevertheless, the result is not satisfying: humankind deprived of Mother Natura's care is not able to acquire proper food; it gathers acorns like animals. Natura, having sympathy with all her "children," complains that she cannot be a good mother to people anymore (III, 39-40). That is why she calls Jupiter a miser and a hard tyrant (durum tyrannum, III, 34) and prefers even Saturn to him. Moreover, it is not only sympathy that matters. We have seen Natura also as a border guard - but the boundaries between humans and animals are not set even after the termination of the Golden Age. ${ }^{48}$

\section{[H]aecine vita iuvat silvestribus abdita lustris, indiscreta feris? ${ }^{49}$}

asks Natura, rebuking Jupiter. After Natura's intervention, Jupiter decides to make it right and becomes calmer (clementior, III, 46). The world order is not going to transform radically and completely, there is not a new ruler coming, but the world has to undergo some smaller changes which can give rise to the art of agriculture (i.e. a civilised way of life). ${ }^{50}$ Every transformation of the world order requires its violation. It is thus chaos that is needed for the spread of agriculture. Here I draw on anthropological concepts ${ }^{51}$ which emphasize the importance of the coexistence of order (structure) and disorder (anti-structure, chaos). Every cultural arrangement is a structured complex. Its structure is, however, limited because every structure (every order) is only a chosen set of norms and rules; many possibilities and aspects of real life are thus excluded from it. This is why every cultural arrangement has to draw its vitalizing power from chaos, which can embrace all aspects in a tangled form. If a transformation of a society is needed, chaos can put the rigid world order in motion with the transformation of the world order as a result: chaotic disorder flows into the existing world order and violates it so that a new transformed world order can emerge. ${ }^{52}$

48 There were no boundaries under Saturn's reign either but Natura does not take this into account, most likely in order to defame Jupiter as much as possible. Changes themselves cannot annoy Natura - she herself was a creator of the world once (I, 147-148; I, 248-270).

49 III, 44-45. 'Does this kind of life please them, hidden away in woodland morasses, an existence indistinguishable from that of wild animals?'

50 Cf. Verg. Georg. I, 121-124 where Jupiter also terminates the Golden Age because of the laziness which it brings about. In contrast to Vergil's Georgics, however, sacrifice and an intervening time between the Golden Age and the Age of Culture are needed here - see also Ware (2012: 182-187).

${ }^{51}$ De Raptu Proserpinae is, of course, focused not only on humankind but also (even mainly) on gods. Nevertheless, the gods in De Raptu Proserpinae are very anthropomorphic, so anthropological approaches are possible here (on this issue, see also Wheeler 1995: 124).

52 It is beyond the scope of this article to explore the importance of different approaches to order and disorder for Claudian's treatment of the myth in detail, but my argument for the usefulness of chaos in this story is based primarily on the concept of structure and anti-structure as developed by one of the Anglo-structuralists Victor Turner. He, like Edmund Leach or Mary Douglas, emphasizes anti-structure: something that deviates from the system, something opposite to structure. In his work The Ritual Process, Turner argues that besides structure (i.e. order), anti-structure is also needed for every cultural arrangement (Turner 1969: 94-130). It is the anti-structure that enables a society to change: one structure can be transformed into another as a result. The important part of the anti-structure is liminality, something that lies "between" (i.e. between two defined states and statuses). He borrows the concept of liminality from van Gennep's The Rites of Passage (1909). These rituals are connected to transitions from one status to another (for example: the transition from childhood to adulthood). Every transition includes a middle phase: the liminal phase. The rituals thus consist of three phases: preliminal rites (rites of separation), liminal rites (rites of transition), and postliminal rites (rites of 
Consequently, Jupiter has another reason to let Pluto enter the upper world. No matter whether or not he decided to establish agriculture initially or just made use of the opportunity, Jupiter definitely needs Pluto's rape and subsequent Ceres' searching for her daughter to teach humankind how to acquire food. He needs these "spurts" or "irruptions" of chaos to violate the existing world order, to reflect deep-rooted relations and values, and to call them into question; thus creating a transformed world order. Ceres, panic-stricken and enraged by misfortune explained to her by Proserpina's nurse, rushes to Mount Olympus to learn the name of the abductor. Jupiter's world order is being endangered by a new threat, but Jupiter chooses not to resolve the conflict. On the contrary, he forbids all the gods from revealing the abductor's name to Ceres because she, after long desperate searching, has to teach agriculture to the man who will inform her about Proserpina. The goddess gets the impression that war, with gods united against her (bella ... caelestia, III, 314), has just begun; and she profanes the sacred grove, the monument of Jupiter's victory over the Giants ${ }^{53}$ and she chops down the trees in order to make a torch. Then she as a Fury (III, 386-391) kindles the torch in Mount Etna. According to her, she would not hesitate to raise a hand against Jupiter himself (ipsum etiam feritura Iovem, III, 359) because he stands against her; because he is unfair (inpius, III, 326).

Chaos is thus not only negative destruction, something to be avoided (something that Jupiter has to minimalize, as we have seen it above): it is a useful dynamic force as well, it also has its positive, creative function. ${ }^{54}$ Its creative potential manifests itself in the intervening time when people suffer and have to live like wild animals, when everything is upside down. In this intervening time, the gods have to suffer as well: young Proserpina is abducted and the gods are only a hair's breadth away from war: the imposition of culture on humankind is - as an event which terminates the intervening time and starts a new period, a transformed world order - also a reversal and disruption of normal conditions and distinctions, of the existing social order. Nevertheless, this reversal is directed by Jupiter (Pluto followed Jupiter's instructions and Jupiter thus transforms Pluto's sudden, spontaneous revolt into a controlled one; Ceres is provoked by Jupiter himself) ${ }^{55}$ Paradoxically enough, an institution of culture, one of the pillars of the world

incorporation) (see van Gennep 1960: 11). In the first stage, people withdraw from their current status and from the society and after the transitional, liminal phase they re-enter the society with a new status. A reversal and confusion of social distinctions is characteristic of the liminal phase (people lose their social status, men behave like women, and people die symbolically...). According to Turner, the liminal anti-structure without the structured order (and this order without the anti-structure) cannot exist successfully: it would result in catastrophe. The liminal, in a way chaotic anti-structure is thus different from pure, unrestrained chaos. On Turner's concepts, see also Chlup (2005: especially 17-27); on structural anthropology, see Chlup (2009: 160-183); on Leach, see Chlup (2011b).

53 The Giants symbolize pure chaos and the motif of Gigantomachy means "the struggle between cosmos and chaos at the most universal level" (Hardie 1986: 85). On the meaning of the Gigantomachy, see Hardie (1986: 85-156); on this motif in Claudian's oeuvre, see Ware (2012: 4, 59-60, 118, 129-141).

54 On positive and negative aspects of chaos, see Girardot (1993).

55 This journey that humankind has to make resembles a rite of passage. Humankind leaves the Golden Age (in which it lived without caring about its livelihood) and gains a new status in the Age of Culture. Between these ages people have to suffer, living like wild animals in the forests and unable to find sustenance. Cf. also the concept of the passage from nature to culture connected with the Athenian ritual called Bouphonia in which Chlup sees a resemblance to van Gennep's three stages of the rites of passage: between nature and culture there is a liminal intervening time when everything is thrown into chaos - see Chlup (2011a: 112; for the whole argument see also Chlup 2011a: 106-112). 
order, arises from chaos. ${ }^{56}$ But it is not a continual alternation of order and chaos: chaos appears in its creative potential and is only a part of a complex process in which order and chaos are interdependent. The fact that the whole process is directed by Jupiter serves as a reduction of the danger contained in chaos. Pluto's raid and Ceres' revolt violate order but in a controlled fashion. ${ }^{57}$

It is the first sailor who functions as Jupiter's model for a courageous journey in a new direction which humankind has to undertake and which is instigated by Jupiter. It is up to humankind to make this journey, but Jupiter is the one who deliberately strives for progress. The first sailor is thus a model not only for Jupiter nor only for humankind, but for them both, for their collective action. Neither the first sailor nor Jupiter is afraid of progress, both of them have to violate established boundaries first of all and risk new, unknown dangers. ${ }^{58}$ The sailor wins in the end, tames the stormy element, and gains control over the sea. In a similar way, Jupiter most likely (as the synopsis in the proem indicates, I, 26-31) wins as well by overcoming difficulties and teaching humankind how to get food with its own hands. Both win thanks to their well-considered steps, the sailor's voyage is guided by sky phenomena (or the gods) and Jupiter, responsible for the whole world, listens to Natura who is not an enemy to him, as she is to the first sailor: she is his mother, parens (III, 45). Humankind, benefiting primarily from progress, is not the originator of the reforms, so it needs to be motivated by someone - and these stimuli of Jupiter's (stimuli $)^{59}$ resemble also another model of progress, namely Hercules' way to glory, whose impetuses were stepmother Juno's stimuli. However, Juno wants to eliminate Hercules, but Jupiter treats humanity in this way for its own good.

What kind of ruler, then, is Jupiter? The destruction of chaotic forces is balanced by keeping the world stable because Jupiter holds the burden of the whole world upon his shoulders, like Hercules when he reaches the peak of his career. He is strict but he lets mother Natura soften him. Natura has the good in her which is also in Orpheus, but not the evil that is within Orpheus as well. Natura is also the originator of Jupiter's clementia, the result of the fusion of Herculean and Orphean principles. However, it does not fall into idyllic, yet dangerous Orphean harmony, which erases not only all the conflicts but also all the boundaries, which constitute the world order. In addition, Jupiter has to make some substantial changes in the world order and this is why he resembles the first sailor. He changes the present world order, but he takes considered steps and listens to Natura, the nature of the world. ${ }^{60}$

56 See Girardot (1993: 215-216), Chlup (2011a: 119-120); cf. Wheeler (1995: 120-121).

57 The similarity between both revolts is pointed out by e.g. Wheeler (1995: 131) or Onorato (2006: 517-527). In contrast, Kellner (1997: 217) mentions that Ceres' revolt is not as dangerous as Pluto's because it is planned by Jupiter.

58 See Jupiter's wish: necessity rerumque remotas / ... vias paulatim exploret 'should gradually investigate the hidden ways of nature' (III, 30-31). On the similarity between this and the first sailor's triumph, see also Schmitz (2004: 41-42).

59 Except initial stimulus, a divine inventor has also to be given by Jupiter.

60 On Natura, see also Duc (1994: 122-123), Kellner (1997: 255-280); on the conception of Natura, a loving mother, and Jupiter, a strict father, see Dupraz (2003: 258-262). 


\section{Ideal form of government?}

Can we regard Jupiter's reign as ideal? Jupiter seems to achieve all his goals, saves the world order successfully and even civilises the world by establishing agriculture. If this is enough to be called ideal, his reign is ideal. Nevertheless, the reader learns precious little about Jupiter's intentions because the narrator is sparing with details. The reader does not know why Jupiter decides to give Proserpina to Pluto nor when he decided to establish agriculture; neither can he be sure what Jupiter feels, nor what his motives are. ${ }^{61}$ The narrator does not reveal any of these things. He spares explicit evaluations, too (in contrast to the narrators of Claudian's political poems $)^{62}$ and in Jupiter's case, he only quotes the ruler's direct speeches or restricts himself to very brief statements. The reader has, therefore, the difficult task of examining the characters of the epic, gauging the consequences of their behaviours, then answering the question of how to judge Jupiter's reign, and finally, deciding what the ideal form of government should look like. Nevertheless, the narrator reveals the complexity of the situation and shows that we cannot expect idyllic harmony even from an ideal ruler.

The Herculean-Orphean model (together with the first sailor's audacity), drawn from the prefaces of the mythical world of the epic, is a useful aid for thinking about what the ideal ruler of the real world should be like. A mythological epic with a story set in such a remote world enables the reader to keep the required distance while searching for the answers. This distance would prove difficult while reading political poems based on real events. However, the Herculean-Orphean model of approaching order-threatening forces can - despite all the differences between the mythological and the panegyric epic - be employed also while reading Claudian's political poems. ${ }^{63}$ In closing, let me hint at one such interpretation. The first two books of the poem De Consulatu Stilichonis constitute a whole: the first book praises Stilicho's Herculean military successes (Stilicho is even compared to Hercules), the second one extols his virtues, especially his clementia, which mitigates the necessary violence in the Orphean way, but which does not erase contrasts ${ }^{64}$ and, like Natura, ${ }^{65}$ creates order from chaos. Stilicho-Hercules holds the world order

${ }^{61}$ Nevertheless, Jupiter seems not to let his emotions run away with him, unlike other characters of this epic. The narrator speaks about Pluto's and Ceres' anger and about Proserpina's instability but he does not attribute something like this to Jupiter. Jupiter himself says that his motive is not and cannot be invidia (III, 26-28). See also Theodosius' advice on self-control in Claud. 8 (Paneg. Hon. cos. IV), 214-418, especially 261-262 tunc omnia iure tenebis, cum poteris rex esse tui 'When thou canst be king over thyself then shalt thou hold rightful rule over the world'.

62 Political poems do not restrict themselves from explicit evaluation with unambiguous representation of good and evil; cf. e.g. quae tibi pro tanti pulso discrimine regni / sufficient laudes, Stilicho? ('What praises shall suffice for thee, Stilicho, who hast freed so great an empire from destruction?', Claud. 26 [Bell. Get.], 13-14).

63 The idea of gradual progress implying breaking present laws (represented by the depiction of the first sailor in De Raptu Proserpinae) is not present in Claudian's political poems. The motif of the first ship can be found at the beginning of Claud. 26 (Bell. Get.), 1-35, but the idea of gradual progress is not highlighted here. Cf., however, Ware (2012: 225-230): according to her, this passage alludes to a dramatic return of the Golden Age.

64 I am leaving aside the question of the relationships in the Golden Age here, whose return is adumbrated in some of Claudian's poems. In any case, it is not a Saturnian harmony at all. On the contrary, Herculean victories are needed for the return of this Golden Age; see e.g. Claud. 3 (In Ruf. I), 368-387 and Ware (2012: 171-230, especially 222).

65 See Keudel (1970: 64-67). 
upon his shoulders (Claud. 21, 142-147) ${ }^{66}$ and mild Clementia, the creator of the world order, dwells in his heart (Claud. 22, 6-29). If the reader is not persuaded by the goal-directed and fragmentary panegyric images of Stilicho, ${ }^{67}$ he can relate them, partly at least, to the Herculean-Orphean model and then examine this model in the mythological epic De Raptu Proserpinae. ${ }^{68}$

\section{REFERENCES}

Cameron, Al., 1970. Claudian. Poetry and Propaganda at the Court of Honorius. Oxford: Clarendon Press. Coombe, C., 2014. 'A Hero in our Midst. Stilicho as a Literary Construct in the Poetry of Claudian'. In: L. van Hoof, P. van Nuffelen (eds.), Literature and Society in the Fourth Century AD. Performing paideia, constructing the present, presenting the self. Leiden / Boston: Brill, 157-179.

Duc, Th., 1994. Le De raptu Proserpinae de Claudien. Réflexions sur une actualisation de la mythologie [= Publications Universitaires Européennes. Série XV. Vol. 67]. Frankfurt am Main: Lang.

Dupraz, E., 2003. 'Sur la différence des sexes dans le De raptu Proserpinae de Claudien'. Revue des études anciennes 105, 251-266.

Dutsch, D., 1991. 'Is Claudian’s “De Raptu Proserpinae” a Non-Political Poem?'. Eos 79, 217-222.

Eliade, M., 1978. A History of Religious Ideas. Volume 1. From the Stone Age to the Eleusinian Mysteries. Transl. from the French by W. R. Trask. Chicago: The University of Chicago Press (paperback edition 1981).

Felgentreu, F., 1999. Claudians „Praefationes“. Bedingungen, Beschreibungen und Wirkungen einer poetischen Kleinform [= Beiträge zur Altertumskunde 130]. Stuttgart / Leipzig: B. G. Teubner.

van Gennep, A., 1960. The Rites of Passage. Transl. from the French by M. B. Vizedom and G. L. Caffee. Chicago: The University of Chicago Press.

Girardot, N. J., 1993. 'Chaos'. In: M. Eliade (ed.), The Encyclopedia of Religion. Vol. 3. $2^{\text {nd }}$ ed. New York: Macmillan Publishing Company, 213-218.

Gruzelier, C. E., 1988. 'Temporal and Timeless in Claudian's De Raptu Proserpinae'. Greece \& Rome. Second Series 35, 56-72.

Gruzelier, C., 1993. Claudian, De raptu Proserpinae. Ed. with transl., introd. and comm. by C. Gruzelier. Oxford: Clarendon Press.

Guipponi-Gineste, M.-F., 2010. Claudien. Poète de monde à la cour d'Occident [Collections de l'Université de Strasbourg. Études d'achéologie et d'histoire ancienne]. Paris: de Boccard.

Hall, J. B., 1985. Claudii Claudiani carmina [Bibliotheca scriptorum Graecorum et Romanorum Teubneriana]. Edidit J. B. Hall. Leipzig: Teubner.

66 The reader understands that it is part of the ruler's task to make compromises: in Claud. 5 (In Ruf. II), 197-219 Stilicho prefers abandoning fighting an enemy to putting his relationship to the emperor of the Eastern Roman Empire, Arcadius, in danger (cf. Cameron 1970: 88-89 and 159-168). On the similarity of the relationship between Jupiter and Pluto and the relationship between the Western and Eastern Roman Empire, see e.g. Ware (2012: 70-71).

67 Despite their impressiveness drawn from mythological imagery; on this, see Coombe (2014: 157-179).

68 The result of Stilicho's activities is, like in the case of Hercules, that Thracia ... flumina (Claud. 21, 132-133) change largo ... sanguine fluctus (Claud. 21, 133). Such victories require something: Stilicho is in the military corps all the time and he can see his wife and his son only rarely (Claud. 21, 116-122); cf. Claud. 26 (Bell. Get.), 296-313. The reader who knows from De Raptu Proserpinae how dangerous Orphean harmony is can understand that such difficulties are necessary. Moreover, there is Calmness / Indulgence, Clementia, in Stilicho's heart, as is shown in the second book of the poem (Claud. 22, 6-29). This Clementia, a crucial virtue for every ruler (Claud. 8 [Paneg. Hon. cos. IV], 277), prima chaos ... solvit / congeriem miserata rudem... 'pitying the elemental confusion, first disentangled Chaos' (Claud. 22, 9-10). What is more, Stilicho's speeches are pleasant like Orpheus' songs (Claud. 22, 168-172); however, the military leader does not become an idyllic harmony-maker. 
Hardie, A., 2007. 'Juno, Hercules, and the Muses at Rome'. The American Journal of Philology 128, 551-592.

Hardie, Ph., 1986. Virgil's Aeneid. Cosmos and Imperium. Oxford: Oxford University Press.

Hardie, Ph., 1993. The Epic Successors of Virgil. Cambridge: Cambridge University Press.

Chlup, R., 2005. 'Struktura a antistruktura. Rituál v pojetí Victora Turnera' [Structure and Antistructure. Victor Turner's Theory of Ritual]. Religio: Revue pro religionistiku 13, 3-28 and 179-197.

Chlup, R., 2007. 'Illud tempus v řeckém rituálu' [Illud Tempus in Greek Ritual]. Religio: Revue pro religionistiku 15, 185-210.

Chlup, R., 2009. 'Strukturální antropologie včera a dnes. Sto let Clauda Lévi-Strausse' [Structural Anthropology Past and Present. One Hundred Years of Claude Lévi-Strauss]. Religio: Revue pro religionistiku 17, 3-35 and 155-184.

Chlup, R., 2011a. 'Illud Tempus in Greek Myth and Ritual'. In: M. Gligor, S. Sabbarwal (eds.), Patterns in Philosophy and Sociology of Religions. Jaipur: Rawat Publications, 91-126.

Chlup, R., 2011b. 'Logika symbolů. Funkcionalistický symbolismus Edmunda Leache' [The Logic of Symbols. The Functionalist Structuralism of Edmund Leach]. Religio: Revue pro religionistiku 19, 51-83.

Johnston, P. A., 1980. Virgil's Agricultural Golden Age. A Study of the Georgics. Leiden: Brill.

Kellner, Th., 1997. Die Göttergestalten in Claudians De raptu Proserpinae. Polarität und Koinzidenz als anthropozentrische Dialektik mythologisch formulierter Weltvergewisserung [= Beiträge zur Altertumskunde 106]. Stuttgart / Leipzig: B. G. Teubner.

Kerényi, K., 2013. Die Mythologie der Griechen. Götter, Menschen und Heroen. Teil I. Die Götter- und Menschheitsgeschichten. Teil II. Die Heroengeschichten. 2. Auflage. Stuttgart: Klett-Cotta.

Keudel, U., 1970. Poetische Vorläufer und Vorbilder in Claudians De consulatu Stilichonis. Immitationskommentar. Göttingen: Vandenhoeck \& Ruprecht.

Leppin, H., 1998. 'Florentinus 1'. In: H. Cancik, H. Schneider (eds.), Der Neue Pauly. Enzyklopädie der Antike. Band 4. Stuttgart / Weimar: Metzler, 564.

Onorato, M., 2006. 'Dissimilis sui. La metamorfosi di Plutone e Cerere nel "De raptu Proserpinae" di Claudiano'. Bollettino di studi latini 36, 516-538.

Pelttari, A., 2014. The Space that Remains. Reading Latin Poetry in Late Antiquity. Ithaca / London: Cornell University Press.

Perkell, Ch., 1989. The Poet's Truth. A Study of the Poet in Vergil's Georgics. Berkeley: University of California Press. Accessible also from: http://ark.cdlib.org/ark:/13030/ft88700889 [8 March 2017].

Platnauer, M. (transl.), 1922. Claudian with an English Translation. I-II [The Loeb Classical Library]. Cambridge, Mass.: Harvard University (3 ${ }^{\text {rd }}$ printing 1963).

Schmitz, Ch., 2004. 'Das Orpheus-Thema in Claudians De raptu Proserpinae'. In: W.-W. Ehlers, F. Felgentreu, S. M. Wheeler (eds.), Aetas Claudianea. Eine Tagung an der Freien Universität Berlin vom 28. bis 30. Juni 2002. München / Leipzig: K. G. Saur, 38-56.

Segal, Ch. (comm.), 2001. Euripides, Bakkhai. Transl. by R. Gibbons. With introd. and notes by Ch. Segal [The Greek Tragedy in New Translations]. Oxford / New York: Oxford University Press.

Turner, V. W., 1969. The Ritual Process. Structure and Anti-structure [Symbol, Myth, and Ritual Series]. Ithaca, New York: Cornell University Press (7th printing 1991).

Vítek, T., Starý, J., 2010. 'Zrcadlení chaosu. Úvodní studie' [The Mirroring of Chaos. An Introductory Study]. In: T. Vítek, J. Starý, D. Antalík (eds.), Řád a chaos v archaických kulturách [Order and Chaos in Archaic Cultures] [= Svět archaických kultur 6]. Praha: Hermann \& synové, 11-45.

Ware, C., 2004. 'Claudian. The Epic Poet in the Prefaces'. In: M. Gale (ed.), Latin Epic and Didactic Poetry. [Swansea, Wales]: The Classical Press of Wales, 181-201.

Ware, C., 2012. Claudian and the Roman Epic Tradition. Cambridge: Cambridge University Press.

Wheeler, S. M., 1995. 'The Underworld Opening of Claudian's De Raptu Proserpinae'. Transactions of the American Philological Association 125, 113-134. 


\section{FIRMIOR HERCULEA MUNDUS CERVICE PEPENDIT. HLEDÁNÍ IDEÁLNÍ FORMY VLÁDY V CLAUDIANOVĚ EPOSU DE RAPTU PROSERPINAE}

Tento článek se zaměřuje na Jovovo panování a hledání ideální podoby vlády v mytologickém eposu De raptu Proserpinae. Navrhuje interpretaci Jovovy vlády, která je založena na významu dvou předmluv eposu. Postavy obou předmluv, první námořník v první předmluvě a Héraklés a Orfeus ve druhé, jsou tak chápány jako modely jednání, které jsou prověřovány a problematizovány v př́iběhu eposu. Ačkoli vypravěč Jovovu vládu explicitně nehodnotí, ukazuje ji jako funkční kombinaci héraklovských a orfických prvků a odvahy prvního námořníka. Tak nabízí De raptu Proserpinae svému čtenáři př́ležitost uvažovat o tom, jak by měla vypadat ideální vláda.

Iveta Pastyříková

Charles University, Prague

pastiveta@gmail.com 